\title{
Oxygen demand during mineralization of aquatic macrophytes from an oxbow lake
}

\author{
Bianchini Jr., I. ${ }^{\mathrm{a}, \mathrm{b} *}$, Cunha-Santino, MB. ${ }^{\mathrm{a}}$ and Peret, AM. ${ }^{\mathrm{a}}$ \\ aPrograma de Pós-Graduação em Ecologia e Recursos Naturais, Universidade Federal de São Carlos - UFSCar, \\ Via Washington Luiz, Km 235, CP 676, CEP 13565-905, São Carlos, SP, Brazil \\ ${ }^{b}$ Departamento de Hidrobiologia, Universidade Federal de São Carlos, - UFSCar, \\ Via Washington Luiz, Km 235, CP 676, CEP 13565-905, São Carlos, SP, Brazil \\ *e-mail: irineu@ power.ufscar.br \\ Received March 17, 2006 - Accepted November 23, 2006 - Distributed February 29, 2008
}

(With 1 figure)

\begin{abstract}
This study presents a kinetic model of oxygen consumption during aerobic decomposition of detritus from seven species of aquatic macrophytes: Cabomba furcata, Cyperus giganteus, Egeria najas, Eichhornia azurea, Salvinia auriculata, Oxycaryum cubense and Utricularia breviscapa. The aquatic macrophytes were collected from Óleo Lagoon situated in the Mogi-Guaçu river floodplain (SP, Brazil). Mineralization experiments were performed using the closed bottles method. Incubations made with lake water and macrophytes detritus (500 mL and $200 \mathrm{mg} . \mathrm{L}^{-1}$ (DM), respectively) were maintained during 45 to 80 days at $20^{\circ} \mathrm{C}$ under aerobic conditions and darkness. Carbon content of leachates from aquatic macrophytes detritus and dissolved oxygen concentrations were analyzed. From the results we concluded that: i) the decomposition constants differ among macrophytes; these differences being dependent primarily on molecular and elemental composition of detritus and ii) in the short term, most of the oxygen demand seems to depend upon the demineralization of the dissolved carbon fraction.
\end{abstract}

Keywords: aquatic macrophytes, oxygen uptake, oxbow lake and kinetic.

\section{Demanda de oxigênio durante a mineralização de macrófitas aquáticas de uma lagoa marginal}

\section{Resumo}

Nesse estudo foi utilizado um modelo cinético para a descrição dos consumos de oxigênio durante a mineralização aeróbia de detritos de sete espécies de macrófitas aquáticas: Cabomba furcata, Cyperus giganteus, Egeria najas, Eichhornia azurea, Salvinia auriculata, Oxycaryum cubense e Utricularia breviscapa. As macrófitas aquáticas foram coletadas na Lagoa do Óleo, situada na planície de inundação do rio Mogi-Guaçu (SP, Brasil). Os experimentos foram realizados empregando-se incubações similares as de DBO. As incubações foram preparadas com água da lagoa e detritos das macrófitas aquáticas (500 mL e $200 \mathrm{mg} . \mathrm{L}^{-1}$ (PS), respectivamente) e foram mantidas durante 45 a 80 dias a $20^{\circ} \mathrm{C}$, sob condições aeróbias e no escuro. Foram determinados os conteúdos de carbono dos lixiviados dos detritos e os consumos de oxigênio dissolvido durante a mineralização. A partir dos resultados obtidos pôde-se concluir que: i) os coeficientes de mineralização das macrófitas aquáticas diferiram entre si, essas diferenças dependeram principalmente das composições moleculares e elementares dos detritos; e ii) a curto prazo, grande parte da demanda de oxigênio parece depender da mineralização das de carbono dissolvido provenientes da lixiviação.

Palavras-chave: macrófitas aquáticas, consumo de oxigênio, lagoa marginal e cinética.

\section{Introduction}

In tropical aquatic systems, the growth of aquatic macrophytes is usually favored by high temperatures and intense solar radiation (Silva and Esteves, 1993; Camargo and Esteves, 1995). Under these conditions, high rates of primary production of macrophytes support trophic food chains and the energy flow of several aquatic ecosystems (Schlickeisen et al., 2003). When an imbalance between primary production and herbivory exist, most of the photosynthetic production is channeled through the detritus

food web. As the detritus undergoes degradation, liberation of carbon and nutrients occurs thus increasing the oxygen demand for oxidation of these compounds. The decomposition of macrophyte detritus depends upon molecular composition (e.g. cellulose, lignin and hemicellulose) and the microbial metabolism food web interactions are also relevant. The tissues of aquatic macrophytes are constituted of fibers (i.e. corresponding mainly to particulate organic matter (POM), soluble organic (dissolved 
organic matter, DOM) and inorganic compounds (Little, 1979; Henry-Silva et al., 2001). During decomposition, these fractions are processed at different rates; in general, the detritus that accumulate in the sediments are basically constituted of fibers (e.g. lignocellulosic matrix). The detritus is constantly modified upon decomposition, under the effects of regulatory forces such as abiotic and biotic factors (Wetzel, 1990; Enríquez et al., 1993; Hohmann and Neely, 1993; Gessner, 2000) and as an outcome of three events: dissolution, fragmentation and catabolism (Mackensen and Bauhus, 1999).

The predominance and specificity of the catabolic route ultimately depends on the availability of oxygen. Aerobic mineralization generates stable end products and tends to transfer more carbon for the growth of microorganisms (Davis and Cornwell, 1991). However, other factors may also change the respiratory coefficients of metabolic processes (e.g. presence of alternative electron acceptors, aliphatic compounds, amino acids, etc.) and interfere in the degradation of organic substances and in the availability of dissolved oxygen (Dilly, 2001). The knowledge of the events associated with decomposition of aquatic macrophytes and of their impact on the environment is important to understand the role played by these organisms in the operation of biogeochemical cycles of ecosystems. This study aimed at describing the kinetic from oxygen uptake and carbon mineralized during aerobic decomposition of detritus; it also compares the decomposition rates and their relationship with the molecular and elemental composition of the detritus by assessing the consumed oxygen from seven aquatic macrophytes (Cabomba furcata Schult. and Schult. f. (1830), Cyperus giganteus Vahl (1805), Egeria najas, Planchon (1849) Eichhornia azurea (Swartz) Kunth (1843), Salvinia auriculata Aubl. (1775), Oxycaryum cubense (Poepp. and Kunth) Lye (1971) and Utricularia breviscapa Wright ex Griseb. (1866)).

\section{Materials and Methods}

\subsection{Sampling site description and samples collection}

Óleo Lagoon $\left(21^{\circ} 36^{\prime} \mathrm{S}\right.$ and $\left.47^{\circ} 49^{\prime} \mathrm{W}\right)$ is one of the many oxbow lakes in the Mogi-Guaçu river floodplain situated within the Jataí Ecological Station ( $21^{\circ} 33^{\prime}$ to $21^{\circ}$ to $37^{\prime} \mathrm{S}$ and $47^{\circ} 45^{\prime}$ to $47^{\circ} 51^{\prime} \mathrm{W}$; municipal district of Luiz Antonio, São Paulo, Brazil). The shallow Óleo Lagoon is $710 \mathrm{~m}$ long and $6 \mathrm{~m}$ wide and on average $2.55 \mathrm{~m}$ deep (Petracco et al., 2006); this is a small $\left(19.470 \mathrm{~m}^{2}\right.$ ), acidic ( $\mathrm{pH}: 5.49 \pm 0.65$ ) lake with relatively low concentrations of dissolved oxygen $\left(3.57 \pm 2.18 \mathrm{mg} . \mathrm{L}^{-1}\right)$ and dissolved organic carbon $\left(3.05 \pm 0.98 \mathrm{mg} . \mathrm{L}^{-1}\right)$. The annual water temperature usually varies from $18 \pm 2{ }^{\circ} \mathrm{C}$ (July) to $30 \pm 1{ }^{\circ} \mathrm{C}$ (January). It has been classified as a seepage lake (Santos et al., 1995) and the littoral zone of this environment is intensely colonized by aquatic macrophytes (Cunha-Santino, 2003).

Water samples were collected at three distinct depths $($ surface $=0.10 \mathrm{~m} ;$ middle $=2.5 \mathrm{~m}$ and bottom $=5.0 \mathrm{~m})$ in the Óleo Lagoon with a Van Dorn bottle. In the labora- tory the samples were mixed, filtered (fiber glass membrane; Millipore $1.2 \mu \mathrm{m}$ ) and aerated for 24 hours.

Seven species of aquatic macrophytes were collected in distinct points from the Óleo Lagoon (Cabomba furcata Gardner, Cyperus giganteus L., Egeria najas Planch, Eichhornia azurea Kunth, Salvinia auriculata Aubl, Oxycaryum cubense Poepp and Kunth and Utricularia breviscapa C. Wright ex Griseb). In the laboratory, the plants were washed with tap water to remove periphyton, sediment particles and coarse material (Osgburn et al., 1987). After washing, the plant material was oven-dried (40-45 ${ }^{\circ} \mathrm{C}$ ), grounded (Tecnal; model TE-650; mesh: $1.41 \mathrm{~mm}$ ) and homogenized. Prior to the assays, aqueous extractions were performed with intact detritus, to obtain the particulate (POM) and dissolved organic matter (DOM) fractions. The extraction comprised addition of $100 \mathrm{~g}$ (DM) of grounded and intact detritus (POM + DOM) in a flask containing $1 \mathrm{~L}$ of distilled and sterilized water (Lush and Hynes, 1978; Anesio et al., 1999; Mфller et al., 1999). After 24 hours of cold aqueous extraction (ca. $4{ }^{\circ} \mathrm{C}$ ), POM was fractionated from DOM through $0.45 \mu \mathrm{m}$ pore size cellulose ester (Millipore).

In order to verify the relative availability of DOM presented in intact fragments of macrophytes, a leaching experiment was set-up according to Mann and Wetzel (1996) and Farjalla et al. (2001). Intact fragments of aquatic macrophytes were exposed to organic-free water (Milli-Q; Millipore) for a 24 hours period. Plants fragments (ca. $0.5 \mathrm{~g}$ ) were placed in an acid-washed glass tube and water with azide abiotic $(0.5 \%)$ in a proportion of 10 g.L $\mathrm{L}^{-1} \mathrm{DM}$. The tubes were maintained under agitation for 24 hours; after leaching period, the samples were filtered through pre-combusted $\left(550{ }^{\circ} \mathrm{C}\right.$ at 2 hours) Whatman GF/F filters and dried while the remaining POM was oven-dried $\left(40-45^{\circ} \mathrm{C}\right)$ and its mass determined by gravimetric method. Non-dispersive combustion and detection in infrared gas analysis (TOC Analyzer, Shimadzu model 5000A) determined the dissolved organic carbon (DOC) in DOM fraction.

\subsection{Experimental set-up}

Laboratory incubations were prepared with lake water added to macrophytes detritus (intact detritus and POM). Oxygen consumption rates were estimated using closed bottle method (Bianchini Jr. et al., 2006). Ground glass stopped bottles ( $\mathrm{n}=3$ for each specie; volume $=500 \mathrm{~mL}$ ) were prepared with water and macrophyte detritus (ca. $200 \mathrm{mg} . \mathrm{L}^{-1}$ (DM) of intact detritus or POM) were aerated for 24 hours; air was passed through a filter in order to eliminate particles and bacteria. Three bottles without macrophytes detritus served as controls. All bottles were closed and incubated in the dark at $20{ }^{\circ} \mathrm{C}$. During sampling days, the concentrations of dissolved oxygen (DO) in the experiment and controls bottles were measured using a polarographic oxygen electrode (YSI, model 58; precision: $0.03 \mathrm{mg} . \mathrm{L}^{-1}$ ). The DO was measured during 50 to 80 days. When the DO concentrations reached 
$2.0 \mathrm{mg} . \mathrm{L}^{-1}$, the incubations were re-submitted to aeration ( 2 hours) with filtered clean air.

\subsection{Adopted kinetic model}

The time evolution of oxygen consumption (OC) was fitted to the first order model (Equation 1; Peret and Bianchini Jr., 2004) with nonlinear regressions method, the algorithm iterative of Levenberg-Marquardt (Press et al., 1993),

$O C=O C_{\text {Max }} \times\left(1-e^{-k_{d} t}\right)$

where: $\mathrm{OC}=$ accumulated value of consumed oxygen; $\mathrm{OC}_{\max }=$ maximum amount of consumed oxygen; $\mathrm{k}_{\mathrm{d}}=$ deoxygenation coefficient (per day); $\mathrm{t}=$ time (day).

Data corresponding to oxygen consumption were log transformed and submitted to variance non-parametric analysis (Kruskal-Wallis test). The level of statistical significance was 0.05 , unless otherwise specified in the test.

\section{Results}

The fragments of macrophytes showed the predominance of particulate organic matter (POM) over the soluble fractions (i.e. DOM; mean $=30.7 \% \pm \mathrm{SD}=5.3 \%$ ). The DOM varied from 22.0 (C. furcata) to $36.1 \%$ (O. cubense) and $\mathrm{C}$ percentile from DOM varied from 4.2 (S. auriculata) to $17.0 \%$ (U. breviscapa; Table 1). On average, POM represented $69.3 \%$ of intact detritus and the dissolution potential (i.e. hydrosoluble protoplasmatic compounds) corresponded to $30.7 \%$.

The oxygen consumption from mineralization of intact detritus $\left(\mathrm{OC}_{\max }{ }^{1}\right)$ and POM $\left(\mathrm{OC}_{\max }{ }^{2}\right)$ is shown in Figure 1 and Table 1 . The mineralization effects (oxygen demand) of dissolved organic carbon (DOC) from Óleo Lagoon were eliminated through incubation by difference; subtracting the oxygen consumption generated in the reference (control) bottles. The deoxygenation coefficient $\left(\mathrm{k}_{\mathrm{d}} \pm\right.$ error $)$ and the determination coefficient ( $\mathrm{r}^{2}$ : variation from 0.96 to 0.99 ) from kinetic fittings of intact detritus is also shown in Figure 1. Mineralization of detritus from submerged species consumed high amounts of oxygen (E. najas: 699.9, U. breviscapa: 496.7 and $C$. furcata: $\left.384.1 \mathrm{mg} \cdot \mathrm{g}^{-1} \mathrm{DM}\right)$. The smallest amount of accumulated oxygen was measured in the mineralization of $S$. auriculata $\left(165.3 \mathrm{mg} . \mathrm{g}^{-1} \mathrm{DM}\right)$. Using the kinetics of oxygen consumption, the Kruskal-Wallis analysis showed significant differences among S. auriculata $\mathrm{OC}_{\max }{ }^{1}$ curve and E. najas $(\mathrm{p}<0.01)$, U. breviscapa $(\mathrm{p}<0.05)$ and $C$. furcata $(\mathrm{p}<0.001)$ decays. This statistical analysis did not indicate significant differences between the kinetics of oxygen consumption from the decay of $C$. giganteus, E. azurea and $O$. cubense (p>0.05). The half-time $\left(\mathrm{t}^{1} / 2\right)$ of the processes were estimated from the deoxygenation coefficients $\left(\mathrm{k}_{\mathrm{d}}\right): 15.5$ and 44.8 days for the mineralization of $C$. furcata and E. najas, respectively. The largest relative contribution for oxygen consumption from POM mineralization (relation between $\mathrm{OC}_{\max }{ }^{2} / \mathrm{OC}_{\max }{ }^{1}$ ) occurred in the detritus of $C$. giganteus (0.70), while the smallest occurred in $O$. cubense $(0.33)$; the mean value of this proportion was $0.53 \pm \mathrm{SD}=0.12$. Based on the results of DOM contents, carbon concentration of DOM (Table 1) and stoichiometric relations between oxygen consumed per carbon oxidized $(\mathrm{O} / \mathrm{C})$ from DOM of these species (Peret and Bianchini Jr., 2004), the maximum oxygen consumed by each kind of leachate $\left(\mathrm{OC}_{\max }^{3}\right)$ was computed, this value varied from

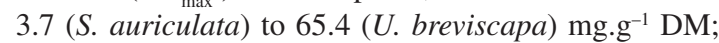
$\left(\right.$ mean $=29.8 \pm \mathrm{SD}=20.2 \mathrm{mg} \cdot \mathrm{g}^{-1}$; Table 1$)$.

\section{Discussion}

The present study allows comparison of kinetics aspects of mineralization of seven aquatic macrophytes species under aerobic conditions. Regarding the DOM content of these plants, the percentile of carbon represented a small

Table 1. $\mathrm{OC}_{\max }$ from aerobic mineralization of intact detritus (POM + DOM), POM and leachate of aquatic macrophytes; DOM content of detritus and carbon content from DOM.

\begin{tabular}{|c|c|c|c|c|c|c|}
\hline Macrophyte & $\begin{array}{c}\text { DOM } \\
\text { leachate }(\%)\end{array}$ & $\begin{array}{c}\text { DOM-C } \\
(\%)\end{array}$ & $\begin{array}{c}\mathrm{OC}_{\text {max }}{ }^{1} \\
\left(\mathrm{mg}^{-1}\right)\end{array}$ & $\begin{array}{c}\mathrm{OC}_{\max }{ }^{2} \\
\left(\mathrm{mg}^{-1} \mathrm{~g}^{-1}\right)\end{array}$ & $\mathrm{O} / \mathrm{C}$ & $\begin{array}{c}\mathrm{OC}_{\max }{ }^{3} \\
\left(\mathrm{mg}^{-1} \mathrm{~g}^{-1}\right)\end{array}$ \\
\hline Cabomba furcata & 22.0 & 14.3 & 384.1 & 204.3 & 1.346 & 42.2 \\
\hline Cyperus giganteus & 27.2 & 4.6 & 316.7 & 221.1 & 1.153 & 14.5 \\
\hline Egeria najas & 27.3 & 8.6 & 699.9 & 396.1 & 1.139 & 26.9 \\
\hline Eichhornia azurea & 35.4 & 8.2 & 279.2 & 124.5 & 1.181 & 34.4 \\
\hline Salvinia auriculata & 34.4 & 4.2 & 165.3 & 104.0 & 0.258 & 3.7 \\
\hline Oxycaryum cubense & 36.1 & 5.0 & 274.9 & 89.6 & 1.181 & 21.4 \\
\hline Utricularia breviscapa & 32.6 & 17.0 & 496.7 & 264.7 & 1.182 & 65.4 \\
\hline Mean & 30.7 & 8.8 & 373.8 & 200.6 & 1.063 & 29.8 \\
\hline Standard Deviation & 5.3 & 5.0 & 176.5 & 108.2 & 0.361 & 20.2 \\
\hline
\end{tabular}

DOM leachate: percentile of DOM derived from intact detritus; DOM-C: percentile of $\mathrm{C}$ from DOM; $\mathrm{OC}_{\max }{ }^{1}: \mathrm{oxygen}$ consumption from intact detritus; $\mathrm{OC}_{\max }^{2}$ : oxygen consumption from particulate fraction $(\mathrm{POM})$ mineralization; O/C: stoichiometric relation derived from aerobic mineralization of leachate of these aquatic macrophytes (according to Peret and Bianchini Jr., 2004) and $\mathrm{OC}_{\max }{ }^{3}$ : oxygen consumption from leachates (computed values). 

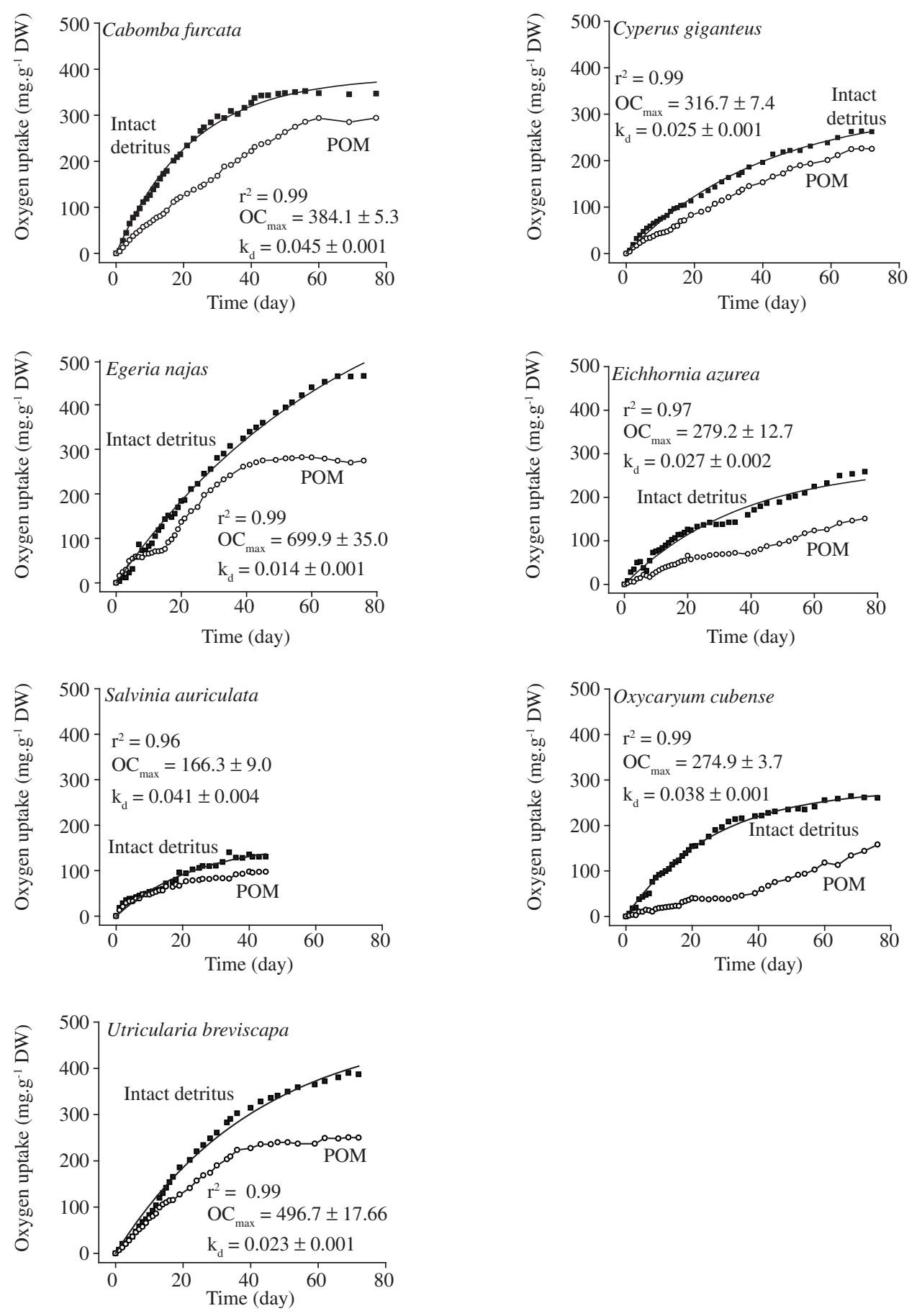

Figure 1. Oxygen consumption kinetics from mineralization of intact detritus $(\mathrm{POM}+\mathrm{DOM})$ and $\mathrm{POM}(\approx$ fibers $)$ from aquatic macrophytes.

fraction of DOM. Referring to the dissolution potential of the intact detritus, the results suggest that submerged $E$. azurea and $O$. cubense contributed more effectively to the DOM pool of the Óleo Lagoon; but did not necessarily supply a higher release of carbon. The species that release higher contents of carbon pool are the submerged (C. furcata and $U$. breviscapa). The lower percentile of cell wall fraction (CWF) was verified for $C$. furcata and $U$. breviscapa. On the other hand, due to the high contents of CWF, the C. giganteus, E. azurea, S. auriculata, E. najas and $O$. cubense are probably the main sources of detritus accumulated in the sediments (Bianchini et al., 2006).

The kinetics patterns of oxygen consumption in the mineralization were similar for intact detritus and POM, 
although a higher consumption was observed during intact detritus than in POM mineralization. The time evolution of oxygen consumption (Figure 1) was similar to that obtained in oxygen uptake long-term experiments (Antonio et al., 1999; Borsuk and Stow, 2000). In the beginning, the consumption was accentuated, but then oxygen consumption rates decreased. Since these resources are heterogeneous (Silva et al., 1994; Henry-Silva et al., 2001), it is supposed that oxidation of labile fractions, basically, represented by protoplasm content of the aquatic macrophytes, occurred in the beginning, and this usually generates high oxygen demands. The oxidation of nitrogenous forms (e.g. nitrification) can also contribute to the consumption starting from the second week of experiments (USEPA, 1985). On the other hand, reductions in the rates of oxygen consumption are expected to be associated with mineralization of the refractory fractions or to consumption of available $\mathrm{C}$ in the DOM. In this context, linear regressions $\left(r^{2}=0.89\right)$ indicated that the processes of oxygen consumption from leachate $\left(\mathrm{OC}_{\max }^{3}\right)$ were directly proportional to the DOM-C content.

In the present study, the detritus of $C$. furcata, E. najas and $U$. breviscapa generated the largest pressures of oxygen uptake in short and medium-term periods on the availability of dissolved oxygen. The mineralization of C. giganteus, E. azurea, S. auriculata and $O$. cubense support the low oxygen demands; it is possible that these species are the main sources of detritus responsible for the benthonic demand of oxygen for the Óleo Lagoon.

The mineralization of these seven species of aquatic macrophytes presented a mean $\mathrm{OC}_{\max }{ }^{1}$ of $373.8 \mathrm{mg} \cdot \mathrm{g}^{-1}$ DM (Table 1); these values were higher than observed for mineralization of Cabomba piauhyensis (Cunha and Bianchini Jr., 1998), Lemna sp. (Bitar and Bianchini Jr., 2002), Montrichardia arborescens (Cunha-Santino et al., 2004), Nymphaea ampla (Brum et al., 1999), Potamogeton stenostachys (Brum et al., 1999), Cabomba sp. (Bitar and Bianchini Jr., 2002), Salvinia sp. (Bitar and Bianchini Jr., 2002), Eichhornia azurea (Bitar and Bianchini Jr., 2002) and Typha domingensis (Farjalla et al., 1999). Other species also showed high values for $\mathrm{OC}_{\max }$ than obtained in the present study: Nymphaea ampla and Potamogeton stenostachys (Farjalla et al., 1999) and Wolffia sp. (Bitar and Bianchini Jr., 2002).

Regarding the mineralization of detritus, it has frequently been associated to the increments of the microorganisms metabolic acting on detritus, usually with high concentrations of nutrients (as DOM) and with low content of recalcitrant structures, such as lignin and cellulose (Gessner, 2000; Komínková et al., 2000). Regarding $\mathrm{OC}_{\max }{ }^{3}$ (OC from leachate) and $\mathrm{OC}_{\max }{ }^{2}$ (OC from POM) we expected that the sum of these two processes were equivalent to $\mathrm{OC}_{\max }{ }^{1}$. Surprisingly, a synergism appears to occur when intact detritus (POM + DOM sources) was decomposing. This fact could be associated to DOM as a nutrient source for heterotrophic activities. The result showed in the present study corroborated with the fact that major fractions of DOM were in inorganic form; in this way, the leachate is mainly constituted by nutrients such as dissolved nitrogen (e.g. ammonia), orthophosphate and total phosphorous (Gupta et al., 1996). In this context, it is supposed that, when detritus cycling is carried out on Óleo Lagoon hypolimniom, the major source of nutrients came from sediment; this process can compensate for the lack of nutrient related with lignocellulosic detritus, increasing consequently, the benthonic oxygen demand.

The mean values of $\mathrm{k}_{\mathrm{d}}$ estimated from other studies on aerobic mineralization of aquatic plants (Cunha and Bianchini Jr., 1998; Lemos et al., 1998; Brum et al., 1999; Farjalla et al., 1999; Bitar and Bianchini Jr., 2002) were 0.180 per day (half-time $=26$ days). This value indicates that, on average, the mineralization process for intact detritus was 5.8 times slower (variation from: 0.014 per day (E. najas) to 0.045 per day (C. furcata). It is supposed that besides the effect from the chemical structure of the detritus, the composition (diversity and number) of the microorganisms may also be responsible for the variation of $\mathrm{OC}_{\max }$ and $\mathrm{k}_{\mathrm{d}}$ values. Considering the predominant environmental conditions of Óleo Lagoon, such as dissolved oxygen availability (mean: $3.57 \mathrm{mg} . \mathrm{L}^{-1}$ ), it is possible that the microflora of this system is not well adapted to the high oxygen availability, as the conditions adopted in the experiments reported here. It has also been suggested that the kinetic coefficients can be affected by qualitative characteristics of the detritus and by physical and chemical factors of the environment (e.g. temperature, Antonio and Bianchini Jr., 2002; and availability of nutrients, Lemos et al., 1998). The $\mathrm{k}_{\mathrm{d}}$ values tended to be inversely proportional to $\mathrm{OC}_{\max }$, which means that for fast decay a relatively reduced oxygen consumption occurs.

Overall, the results from the decomposition of aquatic macrophytes from Óleo Lagoon indicate that: i) the major findings are that decomposition rates differ among macrophytes; these differences depends primarily on the molecular and elemental composition of detritus and ii) most of the oxygen demand seems to depend upon de mineralization of the dissolved carbon fraction.

Acknowledgments - The authors thank the Foundation of Support to Research of the São Paulo State (FAPESP) for the scholarship and for financing these assays (Processes: 98/15011-6; 2000/09297-6; 01/02198-5) and the National Council of Technological and Scientific Development $(\mathrm{CNPq})$ for the scholarship (Processes: 300959/2004-4 e 150169/2004-3).

\section{References}

ANESIO, AM., TRANVIK, LJ. and GRANÉLI, W., 1999. Production of inorganic carbon from aquatic macrophytes by solar radiation. Ecology, vol. 80, no. 6, p. 1852-1859.

ANTONIO, RM., BITAR, AL., BIANCHINI JR., I., 1999. Consumo de oxigênio na mineralização de folhas, galhos, cascas e serapilheira. Acta Limnol. Bras., vol. 11, no. 2, p. 65-78. 
-, 2002. The effect of temperature on the glucose cycling and oxygen uptake rates in the Infernão lagoon water, state of São Paulo, Brazil. Acta Scient., vol. 24, no. 2, p. 291-296.

BIANCHINI JR., I., PERET, AM. and CUNHA-SANTINO, MB., 2006. A mesocosm study of aerobic mineralization of seven aquatic macrophytes. Aquat. Bot., vol. 85, no. 2, p. 163-167.

BITAR, AL. and BIANCHINI JR., I., 2002. Mineralization assays of some organic resources of aquatic systems. Brazil. $J$. Biol., vol. 62, no. 4a, p. 557-564.

BORSUK, ME. and STOW, CA., 2000. Bayesian parameter estimation in a mixed-order model of BOD decay. Water Res., vol. 34 , no. 6 , p. 1830-1836.

BRUM, PR., FARJALLA, VF., GONÇALVES JR., JF., SANTOS, AM., PÔRTO, MT., VIEIRA, EDR., FERREIRA, FM. and BIANCHINI JR., I., 1999. Aspects of uptake of dissolved oxygen in Cabiúnas and Imboassica lagoons (Macaé, RJ). Brazil. Arch. Biol. Technol., vol. 42, no. 4, p. 433-440.

CAMARGO, AFM. and ESTEVES, FA., 1995. Biomass and productivity of aquatic macrophytes in Brazilian lacustrine ecosystems, p. 137-149. In TUNDISI JG., BICUDO CEM. and MATSUMURA-TUNDISI, T. (orgs.), Limnology in Brazil, ABC e SBL, Rio de Janeiro, 376 p.

CUNHA, MB. and BIANCHINI JR., I., 1998. Mineralização aeróbia de Cabomba piauhyensis e Scirpus cubensis. Acta Limnol. Bras., vol. 10, no. 1, p. 81-91.

CUNHA-SANTINO, MB., 2003. Atividade enzimática, cinética e modelagem matemática da decomposição de Utricularia breviscapa da lagoa do Óleo (Estação Ecológica de Jataí, Luiz Antônio - SP). (Tese de Doutorado) - Universidade Federal de São Carlos, São Carlos, SP. 133 p.

CUNHA-SANTINO, MB. and BIANCHINI JR., I., 2002. Estequiometria da decomposição aeróbia de galhos, cascas serapilheira e folhas, p. 185-197. In ESPÍNDOLA, ELG., MAUAD, FF., SCHALCH, W., ROCHA, O., FELICIDADE, N. and RIETZLER, AC. (orgs.), Recursos hidroenergéticos: usos, impactos e planejamento integrado, RIMA, São Carlos, 360 p.

CUNHA-SANTINO, MB., PACOBAHYBA, LD. and BIANCHINI Jr., I. 2004. O/C stoichiometry from mineralization of Montrichardia arborescens (L.) Schott. Acta Limnol. Bras., vol. 16, n. 4, p. 351-357.

DAVIS, ML. and CORNWELL, DA., 1991. Introduction to Environmental Engineering. McGraw-Hill, New York, 822 p.

DILLY, O., 2001. Microbial respiratory quotient during basal metabolism and after glucose amendment in soils and litter. Soil Biol. Biochem., vol. 33, no. 1, p. 117-127.

ENRÍQUEZ, S., DUARTE, CM. and SAND-JENSEN, K., 1993. Patterns in decomposition rates among photosynthetic organisms: the importance of detritus C:N:P content. Oecologia, vol. 94 , no. 4 , p. $457-471$.

FARJALLA, VF., MARINHO, CC. and ESTEVES, FA., 1999. The uptake of oxygen in the initial stages of decomposition of aquatic macrophytes and detritus from terrestrial vegetation in a tropical coastal lagoon. Acta Limnol. Bras., vol. 11, no. 2, p. 185-193.

FARJALLA, VF., ANESIO, AM., BERTILSSON, S. and GRANELI, W., 2001. Photochemical reactivity of aquatic macrophyte leachates: abiotic transformations and bacterial response. Aquatic Microbial Ecol., vol. 24, no. 2, p. 187-195.
GESSNER, MO., 2000. Breakdown and nutrient dynamics of submerged Phragmites shoots in the littoral zone of temperate hardwater lake. Aquat. Bot., vol. 66, no. 1, p. 9-20.

GUPTA MK., SHRIVASTAVA P. and SINGHAL, PK., 1996. Decomposition of young water hyacinth leaves in lake water. Hydrobiologia, vol. 335, no. 3, p. 33-41.

HENRY-SILVA, GG., PEZZATO, MM., BENASSI, RF. and CAMARGO, AFM., 2001. Chemical composition of five species of aquatic macrophytes from lotic ecosystems of southem coast of the state of São Paulo (Brazil). Acta Limnol. Bras., vol. 13, no. 2, p. 11-17.

HOHMANN, J. and NEELY, RK., 1993. Decomposition of Sparganium eurycarpum under controlled $\mathrm{pH}$ and nitrogen regimes. Aquat. Bot., vol. 46, no. 1, p. 17-33.

KOMÍNKOVÁ, D., KUEHN, KA., BÜRSING, N., STEINER, D. and GESSNER, MO., 2000. Microbial biomass, growth, and respiration associated with submerged litter of Phragmites australis decomposing in a littoral reed stand of large lake. Aquat. Microb. Ecol., vol. 22, no. 3, p. 271-282.

LEMOS, RMA., BIANCHINI JR., I. and MAURO, JBN., 1998. Decomposition kinetics of aquatic macrophyte Scirpus cubensis under the influence of dissolved phosphate levels. R. Esc. Minas, vol. 51 , no. 3 , p. $28-31$.

LITTLE, ECS., 1979. Handbook of utilization of aquatic plants. FAO Fisheries Technical Paper No. 187, Rome.

LUSH, DL. and HYNES, HBN., 1978. The uptake of dissolved organic matter by small spring stream. Hydrobiologia, vol. 60, no. 3 , p. $271-275$.

MACKENSEN, J. and BAUHUS, J., 1999. The decay of course wood debris. National Carbon Accounting Systems, Report n. 6. Australian Greenhouse Office, Australia.

MANN, CJ. and WETZEL, RG. 1996. Loading and bacterial utilization of dissolved organic carbon from emergent macrophytes. Aquat. Bot., vol. 53, no. 1, p. 61-72.

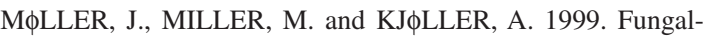
bacterial interaction on beech leaves: influence on decomposition and dissolved organic carbon quality. Soil Biol. Biochem., vol. 31 , no. 3, p. 367-374.

OGBURN III, RW., BREZONIK, PL. and DELFINO, JJ., 1987. Effect of $\mathrm{pH}$ on phosphorous release during macrophyte (Eleocharis sp) decomposition. Water Resour. Bull., vol. 23, no. 5 , p. $829-831$.

PERET, AM. and BIANCHINI JR., I., 2004. Stoichiometry of aerobic mineralization $(\mathrm{O} / \mathrm{C})$ of aquatic macrophytes leachate from a tropical lagoon (São Paulo - Brazil). Hydrobiologia, vol. 528, no. 1-3, p. 167-178.

PRESS, WH., TEUKOLSKY, SA., VETTERLING, WT. and FLANNERY, BP., 1993. Numerical Recipes in C: The Art of Scientific Computing. Cambridge University Press, New York, $994 \mathrm{p}$.

PETRACCO P., 2006. Efeito das variáveis abióticas na produção primária de Egeria najas e Utricularia breviscapa da lagoa do Óleo (Estação Ecológica de Jataí, Luiz Antônio $S P) .145$ p. (Tese de Doutorado) - Universidade Federal de São Carlos, São Carlos, SP.

SANTOS, JE., BALLESTER, MVR., JESUS, TP., PIRES, JSR. and OBARA, AT., 1995. Abordagem sistêmica para o manejo de áreas naturais de conservação. Caso de estudo: Estação 
Ecológica de Jataí, Luiz Antônio, SP. Oecol. Brasil., no. 1, p. 487-502.

SCHLICKEISEN E., TIETJEN, TE., ARSUFFI, TL. and GROEGER, AW., 2003. Detritus processing and microbial dynamics of an aquatic macrophyte and terrestrial leaf in a thermally constant, spring-fed stream. Microb. Ecol., vol. 45, no. 4 , p. 411-418.

SILVA, CJ. and ESTEVES, FA., 1993. Biomass of three macrophytes in the Pantanal of the Mato Grosso, Brazil. Int. J. Ecol. Environ. Sci., vol. 19, no. 1, p. 11-23.
SILVA, CJ., NOGUEIRA, F. and ESTEVES, FA., 1994. Composição química das principais espécies de macrófitas aquáticas do Lago Recreio, Pantanal Matogrossense (MT). Braz. J. Biol., vol. 54, no. 4, p. 617-622.

USEPA - UNITED STATES ENVIRONMENTAL PROTECTION AGENCY, 1985. Rates, Constants and Kinetics Formulations in Surface Water Quality Modeling. $2^{\text {nd }}$ ed. EPA/600/3-85/040. U.S. Government Printing Office, Athens.

WETZEL, RG., 1990. Detritus, macrophytes and nutrient cycling in lakes. Mem. Ist. Ital. Idrobiol., vol. 47, p. 233-249. 
